\title{
IFN-gamma Receptor 1 Deficiency
}

National Cancer Institute

\section{Source}

National Cancer Institute. IFN-gamma Receptor 1 Deficiency. NCI Thesaurus. Code C126337.

A condition of decreased or absent presence or activity of interferon gamma receptor 1.

Deficiency of this protein is associated with immunodeficiency 27A and immunodeficiency 27B. 